International Journal of Engineering \& Technology, $7(2.29)(2018) 787-791$
SPC
International Journal of Engineering \& Technology
Website www.sciencepubco.com/index.php/IJET
Research paper

\title{
Strategic Design of Information System Implementation at University
}

\author{
Wahyudin Darmalaksana ${ }^{1 *}$, Muhammad Ali Ramdhani ${ }^{2}$, Rinda Cahyana ${ }^{3}$, Abdusy Syakur Amin ${ }^{4}$ \\ ${ }^{1}$ Research And Publication Center, UIN Sunan Gunung Djati Bandung, Indonesia \\ ${ }^{2}$ Department Of Informatics, UIN Sunan Gunung Djati Bandung, Indonesia \\ ${ }^{3}$ Department Of Informatics, Sekolah Tinggi Teknologi Garut, Indonesia \\ ${ }^{4}$ Department Of Industrial Engineering, Universitas Pasundan, Indonesia \\ *Corresponding Author E-Mail: Yudi_Darma@Uinsgd.Ac.Id
}

\begin{abstract}
Higher education over the past decade has experienced several view changes that include: paradigm shift, management and competition changes, and so forth. The only university supported by the excellent IT that will be able to enhance and maintain its advantages. The purpose of this article is reviewing the strategic design of IT implementation at the university. The analysis used to reveal the fact, problem and problem-solving in this article adopts the model of Strategic Management of Information Technology (SMIT) developed by Flodström. The strategy design of IT implementation based on the competitive environment of UIN Sunan Gunung Djati Bandung is coordinated with its business strategy. The role of IT as an enabler or tool that allow the university to be able to create cheaper-betterfaster educational process. In this article, there are designed two types of IT Functions: back office and front office. For back office application function, there is a software management with specific modules to support the implementation of university management. In the front office function of IT usage, there are some types of IT usage concepts that directly and indirectly affect the way of establishing education that leads to quality improvement which can be implemented through: media simulation, course management, virtual class, computer-based training (CBT), knowledge portal and cyber community. The strategic design of IT implementation presented in this article is a generic model of the plan, design, and implementation of IT in the object of study.
\end{abstract}

Keywords: competitive environment; e-university; information technology; strategic management

\section{Introduction}

Higher Education/ university is an institution that has a core task in the development of knowledge, which in the present context, the position of knowledge tends to be stronger in every aspect of human life [1]. One of those which are enable efficiency and effectiveness in business process within a field of business process in university is information systems. Information systems (IS) is a combination of information technology utilizations and human activity upon a set of agreed procedure [2], generally is used to support management and operation [3]. IS is an organized data process [4], IS has a high level of flexibilities to develop and scalable [5]. Refers to several research, an information system has a high capability in decision making, the system has an accurate data accessibility and efficient run-time [6], high accuracy [7], and to support a proper decision [8], low cost [9], extended accessibility [10], intensify user knowledge [11], increase productivity [12], provide a better data and information [4], and used as data storage [13].

The implementation of university contains at least five dimensions, namely (1) knowledge dimension, (2) education dimension, (3) social dimension, (4) ethical dimension, and (5) corporate dimension. In the corporate dimension, a university is required to be able to survive in facing environmental turbulence so-called hyper-competitive environment, where the University as an organization, is also facing more intensive competition, a condition that has battle positions between price and quality, a new science creation of, and benefits development as a pioneer/ first-mover advantage [14].

The implementation of university experienced view changes over the last decade. The view changes included paradigm change, management change, competition change, and so on. The paradigm change was primarily driven by the development of information technology (IT) [15], which as implemented as an instrument in administration, teaching, research [16], and community service. IT helps the process of converting knowledge in the form of data, which is stored, analyzed and converted into information $[17,18,19]$ and then delivered to the user through the IT instrument called Academic Information Channel, namely electronic information media used to obtain academic information automatically with or without a transmission media [20]. The mastery and control of information [21] with IT provide benefits such as the improvement of learning outcomes [22]. In addition, the implementation of IT makes a job effective, efficient, and flexible [10], although on the other hand, it burdens university with a cost of IT infrastructure [16] for the provision of platform, persons, and services [23].

This implied that the implementation of IT in education is no longer considered an option, but it becomes an absolute necessity that should be owned and utilized by the university when attempting to improve the quality of education. Only a university supported by an excellent IT, which will be able to enhance and maintain its superiority. This article aimed at reviewing the strategic design for the implementation of IT in higher education. 


\section{Methodology}

The methodology employed this study which revealed the facts and issues adopted the model of Strategic Management of Information Technology (SMIT) developed by Flodström [24]. SMIT is a holistic framework of the IT-based strategic management framework.

The fact of IT implementation was presented in the form of environmental analysis, which includes an organization business. The competitive environment is often called an environment affecting strategy election, where the strategy selection will influence the competitiveness of an institution/ organization. The competitive environment is an external condition that may influence the business competitiveness of an organization. Competitive advantage is, in fact, meaningless as a concept unless it is used in the context of a given competitive environments. An advantage has to be gained over something other than the processor of the advantage, in respect of some criteria relevant to a common objective and in relation to a given location and competitive environment [25]

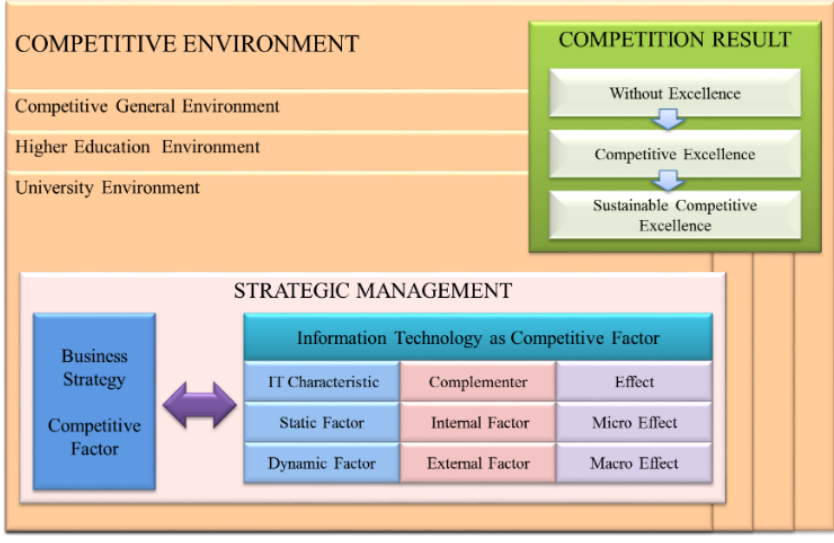

Fig. 1: Competitive Environment

The limitation of the internal environment is restricted by the work area of the organization, and the external environment outside the organization. In the analysis of IT implementation work plan at university, the competitive environment includes:

a. University environment associated with the place in which a university competes; and

b. The business unit environment includes an environment represented by the organization, to get customers and added value.

The identification of general environment can be employed by three techniques:

a. Identification of relevant external factors with a model to analyze the political, economic, social, and technological factors (PEST)

b. Identification of trends related to the strategic need to predict how the environment will change.

c. Identification of global environment associated with the global work manner by utilizing IT.

The competitive environment is directly related to three factors: competitive strategy, competitive factor, and competitive result Figure 2 is a framework that illustrates the relationship between the three factors.
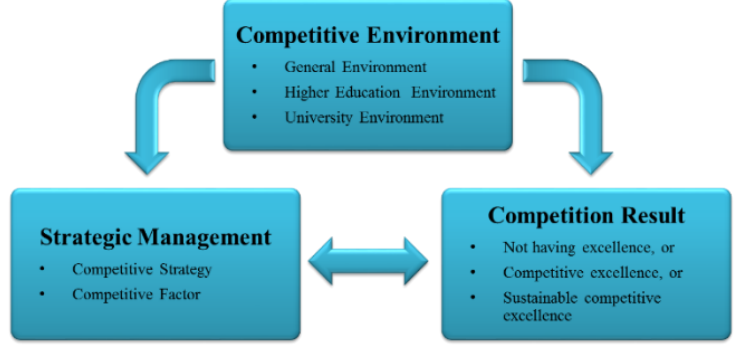

Fig. 2: Framework for Competitive Environment
As shown in Figure 2, the analysis result of competitiveness is based on the environment currently happening, and changes in the future. The analysis result of competitiveness will be affected by the adopted strategy and in the form of competitive advantage which is temporary, sustainable, or which does not give any advantage at all. Strategic management will determine whether a competitive advantage can be maintained or increased in accordance with the environmental condition. Thus, competitiveness is influenced by strategic management and not directly influenced by the environment.

Although the purpose of the strategy is achieving excellence, strategy possibly does not make it. For example, if an organization only invests a technology or follow a technology used by its competitors, it may not provide any advantage, because excellence can only be achieved by using the right technology to support business and create added value.

In addition to investment, it is necessary for an organization to have an adequate level of intelligence to get a value or significant benefit from IT [26, 27]. The intelligence of IT brings to [18]:

$a$. The efficiency of cost, time, and information resource usage.

$b$. The effectiveness of IT in supporting business strategy, as an enabler for business process, improving structure and culture, and enhancing customer value and business.

According to Flodström (2006), the implementation of technology does not provide a sustainable competitive advantage because technology is generally available so it possibly provides the same advantages for organization and competitor [24]. The competitive advantage of technology is highly dependent on how the technology is used, in which its usage may be different in each organization, depending on the availability of human resource and a number of other capabilities, such as financial and infrastructure supports.

\section{Result and Discussion}

\subsection{Problem Formulation}

In principle, there is three core processes of higher education activities employed at the university, namely (1) teaching; (2) research; and (3) service/ community service. In order that the university can effectively perform the three processes, it needs a number of supporting activities related to the following points: academic administration, finance and accounting, human resources, campus infrastructure, and so on (Figure 3).

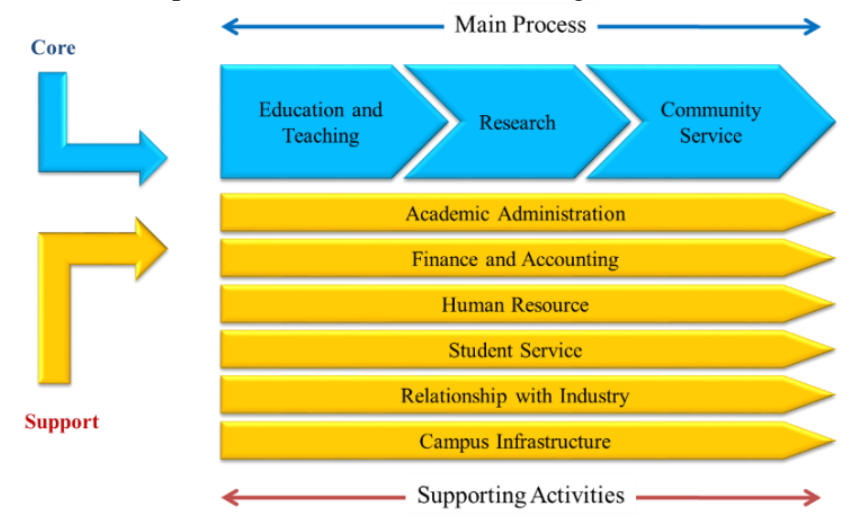

Fig. 3: Core and Supporting Activities at University

Objectives identification and university process and activity categorization are intended to assist management in allocating their resources in order to support the vision, mission, and goals that have been planned. Based on the results of university mapping, there are a lot of stakeholders (interested parties) of potential users of the IT application at the university. There have been found at least eight stakeholders that are closely related to the core processes as well as supporting activities of a university. The stakeholders are: students and alumni, faculty, industry, community, other edu- 
cational institutions, university management, employees, and government (Figure 4)

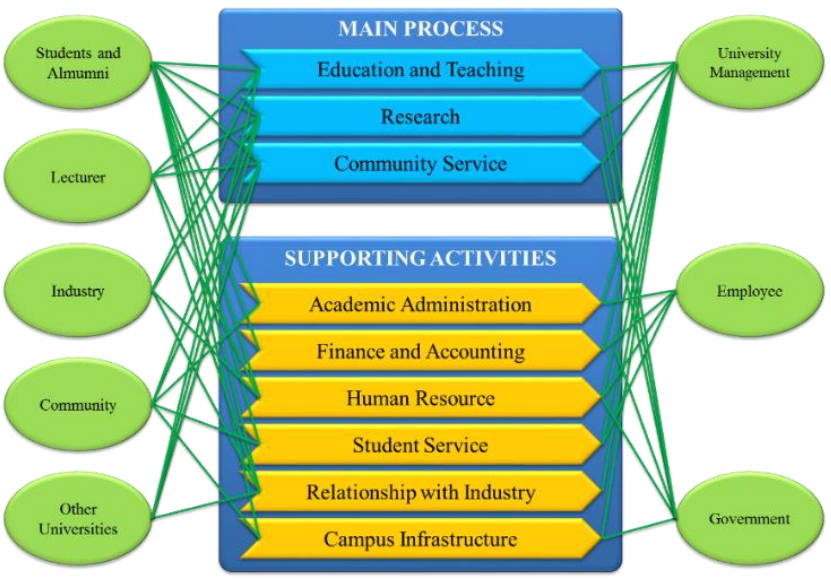

Fig. 4: Process and Stakeholder Relations

Based on the above mapping, there should be an interface model of the information systems that connects each stakeholder to the main processes and supporting activities at the university. Product and service of a university vary in nature in which each of the product and services will have different users, both externally and internally. Problems arise when diverse stakeholders have different purposes. In Table 1 there are presented the objectives to be achieved in each of the stakeholders within a framework of university management.

Table 1: Matrix Process and Stakeholders Interests

\begin{tabular}{|c|c|c|}
\hline \multirow{2}{*}{ Stakeholders } & \multicolumn{2}{|l|}{ Type Proses } \\
\hline & Main Process & Supporting activities \\
\hline Student & Quality of education & $\begin{array}{l}\text { Effective, efficient, and } \\
\text { flexible }\end{array}$ \\
\hline Lecturer & $\begin{array}{l}\text { Quality of facility, } \\
\text { knowledge, academic } \\
\text { culture }\end{array}$ & $\begin{array}{l}\text { Simplicity and flexibility } \\
\text { in bureaucracy }\end{array}$ \\
\hline Industry & New product, benefit & Control of contract \\
\hline Society & $\begin{array}{l}\text { Product/ new program, } \\
\text { tertiary education }\end{array}$ & Low and achievable cost \\
\hline $\begin{array}{l}\text { Other Univer- } \\
\text { sities }\end{array}$ & Cross registry & operational cooperation \\
\hline $\begin{array}{l}\text { University } \\
\text { Management }\end{array}$ & Additional value & $\begin{array}{l}\text { cost suppression, invest- } \\
\text { ment utilization }\end{array}$ \\
\hline Staff & Administration services & $\begin{array}{l}\text { Sufficient payment, em- } \\
\text { powerment }\end{array}$ \\
\hline Government & $\begin{array}{l}\text { Regulation of manage- } \\
\text { ment, Quality of educa- } \\
\text { tion }\end{array}$ & Reporting Standard \\
\hline
\end{tabular}

From the eight major stakeholders, there are at least 5 (five) main customers, namely: students, faculty, industry, community, and other educational institutions.

Therefore, the core excellence of university is how to offer products and services related to the three principles of university performed to satisfy stakeholders. This implies that the principal issue in the application of IT at university is the ability to accelerate goals and meet stakeholders' needs effectively and efficiently, with the following efforts:

a. Providing IT tools that can be used by all stakeholders.

b. Providing on-line and real-time information access about the university through the internet so that stakeholders easy access to obtain complete information in accordance with their needs.

\subsection{Role and Function of IT}

The implementation of IT provides business value in the form of flexibility, quality improvement, cost reduction and productivity improvement $[28,29,30]$. Efficiency is achieved through the application of IT aligned with organization's plan and strategy, as well as information requirement that determines the success of an organization. Information and IT instrument is expected to improve the competitiveness of the organization that leads it to the goals, increases strength and opportunity, and reduce obstacle and weakness of the organization.

IT at university functions as a supporter and an accelerator for the services provided by university and information access by users for the purpose of efficiency within all processes working in higher education. University excellence can be achieved by ongoing extracting the information needs and following the development of IT.

\begin{tabular}{|c|c|c|}
\hline \multirow{4}{*}{ Supporter } & FUNCTION & \multirow{4}{*}{$\begin{array}{c}\text { Efficiency and } \\
\text { Effectiveness of } \\
\text { Teaching, Research, } \\
\text { and Community } \\
\text { Service }\end{array}$} \\
\hline & Improving Campus Service & \\
\hline & Fulfilling Information Need & \\
\hline & Accelarator & \\
\hline \multicolumn{2}{|r|}{ ROLE } & \\
\hline & University & \\
\hline
\end{tabular}

Fig. 5: Role, Function, and Purpose of Information Technology

\subsection{Implementation of IT at University}

Competitive results through the implementation of IT activities that university desires are as follows:

a. Integrated insight capabilities for the growth of the university.

b. Creating a conducive working condition. It is necessary to make favorable conditions so that academic community can give their best for the implementation and development of the university.

c. University curriculum and material development.

The strategy of IT implementation based on university competitive environment is in line with its business strategy. The role of IT as enabler or tool that allows the university to establish cheaperbetter-faster education process. There are two functions of IT dealing with this issue, back office and front office.

The back office is the use of IT to support the process of the administration implementation of the university or often so-called operational activity. Here are the targeted things within the implementation of IT:

a. On-line registration that uses website so that prospective students around the world can access without having to physically come to a university concerned;

b. On-line Study Plan Form that allows the administration of courses contracts conducted anywhere using digital devices such as computers, PDAs (Personal Digital Assistant), tablet PCs, and so forth;

c. Students can see the score of test and the final results of study via the internet or mobile phone device they owned;

d. Classes management ranging from the allocation of subject and lecturer until student attendance is employed automatically with a special application;

e. Documentation and archives system is stored neatly in electronic format using EDMS (Electronic Document Management System) based application;

f. Integrated human resource management concerning data and information record of students, faculty, and alumni;

g. Books and journals library that can be accessed from anywhere and at any time ( 24 hours a day, 7 days a week);

h. Integrated information systems related to the functions of marketing, administration, human resources, finance and accounting, asset management, and so forth;

i. Integrated administration between universities which allow students to take courses in cross-study programs or different universities;

j. Application of employing research and public service that range from the process of proposal submission until the evaluation of research results and the implementation of related programs; 
k. Software to manage the hierarchy system of employee's career and lecturers rank;

1. Information portal that allows university academic community to find a variety of important data and information at the university and other partner institutions;

m. supporting means for students in making and evaluating the study plan, and so forth.

Regarding the function of back office application, one example of application best practice which can be employed by the university is a software with specific modules to support the administration of university management.

As for the types of application, there are three ways of procurement, namely: buying a ready package of application to be implemented (without being able to make any change to the blocks constituent), creating its own application (ranging from analysis, design, until construction and implementation), combining several types of applications into one (with interfacing systems), buying a ready-made application that can be customized (tailor-made) or a combination of all four approaches. Conceptually, the collection of blocks of the application can be shown in Figure 6.

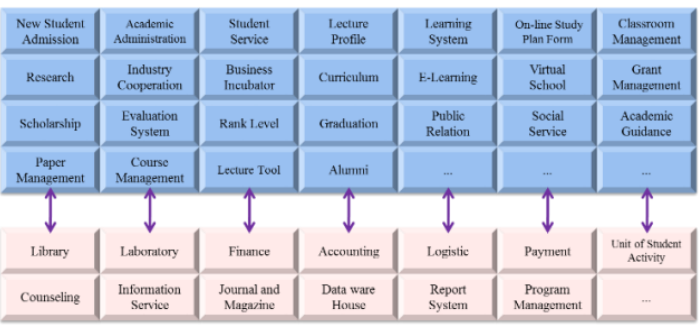

Fig. 6: Application Blocks

In the front office functions of the IT use, there are many different concept types of IT usage that directly and indirectly influence the way of providing education that leads to quality improvement, for example, it is implemented via:

\section{a. Simulation Media:}

IT as a medium to assist lecturers in employing lectures is mainly used as a means of depiction or illustration so that students get a description of the theory taught in the classroom more easily, especially that is related to its implementation in the real world [31]. Included in this category are the applications such as $\mathrm{CAD} / \mathrm{CAM}$, simulation game, multimedia presentation, interactive study case, and so forth. Multimedia is a digital product that serve and combine text, audio, image, animation, and video which are implemented by tools and link. Users are able to navigate, interact, work and communicate [32]. In education, multimedia is utilized as a learning media in both in a specific class and self-taught [33]. The use of multimedia in a learning process are evidently able to create an enjoyable learning [34], develop student motivation [35], increase effectiveness in learning process [36], intensify comprehension [37], create a student-centric system, and investment efficiency in learning tools [38].

\section{b. Course Management}

The following concept of IT use is to help teacher and students in interaction, cooperation, and communication of a class organization with a specific subject [32]. With the help of a webbased application, material, teaching material, administration program, homework, and others can be downloaded by students via the Internet. In addition to the media functioning to help resources management in a course implementation, the Internet can also be used to increase the intensity and quality of interaction between teacher and students and between students themselves. For example, they can communication facilities such as electronic mail (e-mail), discussion, chatting, teleconference, and so forth.

\section{c. Virtual Class:}

The next concept is that it allows the implementation of the virtual class using information technology. Implementation of this concept works evolutionary, in the sense that it is developed slowly toward the actual virtual class.

\section{d. Computer Based Training (CBT):}

CBT concept is a very powerful way employed by a university wishing to promote the principle of self-directed learning. In the past, students could only use book-based library facility to increase their knowledge, in the present time there has been provided a number of software that can help students to learn without having been assisted by a guide and without physically attending classes because of CBT. In implementing CBT, every student is given a CD-ROM or access to a site on the internet as if the student was in a class with a teacher as an instructor, and through the interesting application of multimedia, students learn the material they want to master in an interactive and structured manner. The principle of multimedia application development does not only aim to make an interesting learning process but also is intended to run effectively and contextually.

\section{e. Knowledge Portal:}

University is an institution or organization whose quality is highly dependent on its knowledge base. It required a knowledge portal as a channel for the academic community to interact with each other [2]. For the purposes of teaching and research, students and lecturer are highly dependent on the progress or development of science practiced, where data or information related to their science spreading in all educational institutions must be easily accessible to the academic community. The internet existence with the application of knowledge portal or search engine is an absolute device that must be owned by the institution. Supported by the expertise and sufficient competence in doing an advanced search on the internet, a lecturer can search many types of knowledge on the internet such as:

1) a collection of current journals regarding the occupied areas of study;

2) courses syllabus in many universities in the world for comparison;

3) course material in the form of presentation or electronic file format (such as an e-book) complete with sample questions for quizzes and exams;

4) a variety of case studies of the application of related science in many sides of human life;

5) research results of the world's leading institutions conducted and published by non-profit and commercial institutions nature; etc.

\section{f. Cyber Community:}

For professional lecturer, interaction with other academic community all over the world is an absolute necessity that must be considered seriously. Relationships with the professor and leading industry figures in any country can be done very easily, cheaply and quickly by utilizing ICT. Today, the community that interacts via the virtual world has grown very fast in which they use technology such as:

1) Electronic Mail, to interact directly with concerned individuals to meet the needs of communication, collaboration, and cooperation with respect to joint research employed;

2) Mailing List, as a media or forum of communication intergroup to discuss a theme of specific knowledge according to the needs or interest;

3) Discussion Forum, an application where the process of discussion of different themes effectively occur between lecturers from different study programs, universities, and countries;

4) Chatting, real-time mechanism allows some people simultaneously chat to discuss trending topics and require special knowledge;

5) Teleconference, 'face to face' by using camera and multimedia device that may involve more personal video and audio; and

6) Search Engine, an application that assists lecturer to: search for research funding, know the international seminar held all over the world, send a journal or scientific article to respond the call for papers, gain research cooperation opportunity with industry, prepare a research proposal, and so forth etc. 


\section{Conclusion}

IT development today is very fast and significant. The development led to the role changes of technology in business world or organization, including university. This role ranges from efficiency, effectiveness, to strategic role. The role of efficiency replaces humans with more efficient IT, the role of effectiveness is providing information for effective management decision making. Meanwhile, the role of information technology does not only cover efficiency and effectiveness but also enters the strategic space, which is used to win the competition. Because of its strategic role, IT is often called a strategic weapon utilized as a powerful tool to compete. And even today, IT is also called an enabler that enables an organization to gain competitive excellences.

The role of IT as a tool enables the university to make cheaperbetter-faster educational process. The program of an information system that needs developing at the university may include:

a. Preparing a development pattern of the integral information system.

b. Developing and arranging Web-based Information System Software of the university.

c. Developing Academic Information System Software and socializing it to the entire academic community.

It is believed that the implementation of IT will be able to improve academic services, which in turn will enhance the competitive excellence of the university.

\section{References}

[1]. Ramdhani, M. A., \& Suryadi, K. (2006). Analisis Faktor-faktor Kunci Keberhasilan dalam Penerapan Knowledge Management pada Perguruan Tinggi. 4th Indonesian Symposium on Analytic Hierarchy Process. Jakarta: Universitas Trisakti.

[2]. Pamoragung, A., Suryadi, K., \& Ramdhani, M. A. (2006). Enhancing the Implementation of e-Government in Indonesia Through the HighQuality of Virtual Community and Knowledge Portal. 6th European Conference on e-Government (pp. 341-347). Marburg: Academic Conferences Limited.

[3]. Ramdhani, M. A. (2013). Metodologi Penelitian untuk Riset Teknologi Informasi. Bandung: UIN Sunan Gunung Djati Bandung.

[4]. Maylawati, D. S., Darmalaksana, W., \& Ramdhani, M. A. (2018). Systematic Design of Expert System Using Unified Modelling Language. IOP Conference Series: Materials Science and Engineering, 288(1), 012047

[5]. Aulawi, H., Ramdhani, M. A., Slamet, C., Ainissyifa, H., \& Darmalaksana, W. (2017). Functional Need Analysis of Knowledge Portal Design in Higher Education Institution. International Journal of Soft Computing, 12(2), 132-141.

[6]. Slamet, C., Rahman, A., Sutedi, A., Darmalaksana, W., Ramdhani, M A., \& Maylawati, D. S. (2018). Social Media-Based Identifier for Natural Disaster. IOP Conference Series: Materials Science and Engineering, 288(2017), 012039.

[7]. Slamet, C., Andrian, R., Maylawati, D. S., Suhendar, Darmalaksana, W., \& Ramdhani, M. A. (2018). Web Scraping and Naïve Bayes Classification for Job Search Engine. IOP Conference Series: Materials Science and Engineering, 288(2017), 012038.

[8]. Gerhana, Y. A., Zulfikar, W. B., Ramdani, A. H., \& Ramdhani, M. A (2018). Implementation of Nearest Neighbor using HSV to Identify Skin Disease. IOP Conference Series: Materials Science and Engineering, 288(2017), 012153.

[9]. Rahman, A., Slamet, C., Darmalaksana, W., Gerhana, Y. A., \& Ramdhani, M. A. (2018). Expert System for Deciding a Solution of Mechanical Failure in a Car using Case-based Reasoning. IOP Conference Series: Materials Science and Engineering, 288(2017), 012011.

[10]. Slamet, C., Rahman, A., Ramdhani, M. A., \& Darmalaksana, W. (2016). Clustering the Verses of the Holy Qur'an using K-Means Algorithm. Asian Journal of Information Technology, 15(24), 5159-5162.

[11]. Maylawati, D. S., Ramdhani, M. A., Zulfikar, W. B., Taufik, I., \& Darmalaksana, W. (2017). Expert System for Predicting the Early Pregnancy with Disorders using Artificial Neural Network. 5th International Conference on Cyber and IT Service Management Denpasar.

[12]. Zulfikar, W. B., Jumadi, Prasetyo, P. K., \& Ramdhani, M. A. (2018). Implementation of Mamdani Fuzzy Method in Employee Promotion System. IOP Conference Series: Materials Science and Engineering, 288(2017), 012147.
[13]. Taofik, A., Ismail, N., Gerhana, Y. A., Komarujaman, K., \& Ramdhani, M. A. (2018). Design of Smart System to Detect Ripeness of Tomato and Chili with New Approach in Data Acquisition. IOP Conference Series: Materials Science and Engineering, 288(2017), 012018.

[14]. Nasution, H. N. (2004). Orientasi Pasar; Konsep, Relevansi, dan Konsekuensi. Jurnal Usahawan, 23(6), 3-9.

[15]. Indrajit, R. E., \& Djokopranoto, R. (2004). Manajemen Perguruan Tinggi Moderen. Jakarta: Sekolah Tinggi Manajemen Informatika dan Komputer PERBANAS.

[16]. Educause. (2010, June 27). Funding Information Technology : an Educause Executive Briefing. Retrieved from Educause: http://net.educause.edu/ir/library/pdf/pub4002.pdf

[17]. Low, L. (2000). Economics of Information Technology and the Media. Singapore: University Press.

[18]. O'Brien, J. A., \& Marakas, G. M. (2008). Management Information System. New York: Mc-Graw-Hill Companies, Inc.

[19]. Turban, E., Leidner, D., McLean, E., \& Wetherbe, J. (2006) Information Technology for Management: Transforming Organization in the Digital Economy. J. Wiley \& Sons.

[20]. Cahyana, R. (2014). The Service Candidate Modelling of Academic Information Channel by Appliying of Service Oriented-Architecture International Journal of Basic and Applied Science, 2(4), 93-97.

[21]. Fenner, A. (2002). Placing Value on Information. Library Philosophy and Practice, 4(2), 1-6.

[22]. European Schoolnet. (2006). The ICT Impact Report : A review of studies of ICT impact on schools in Europe. European Communities.

[23]. Rainer, R. K., \& Cegielski, C. G. (2011). Introduction to Information Systems. John Wiley \& Sons, Inc.

[24]. Flodström, R. (2006). A Framework for the Strategic Management of Information Technology. Department of Computer and Information Science Linköpings Universitet: Linköping.

[25]. Pitkethly, R. (2003). Analysing the Environment. In D. Faulkner, \& A Campbell, A Strategy Overview and Competitive Strategy (pp. 226-260). New York: Oxford University Press.

[26]. Weill, P., \& Ross, J. W. (2004). IT governance: How top performers manage IT decision rights for superior results. Boston: Harvard Business School Press Books.

[27]. Weill, P., \& Aral, S. (2006). Generating Premium Returns on Your IT Investments. Sloan Management Review, 39-48.

[28]. Melville, N., Kraemer, K., \& Gurbaxani, V. (2004). Review: Information Technology and Organizational Performance: An Integrative Model of IT Business Value. MIS Quarterly,, 28(2), 283-322.

[29]. Dedrick, J., Gurbaxani, V., \& Kraemer, K. L. (2003). Information technology and economic performance: A critical review of the empirical evidence. ACM Computing Surveys, 35(1), 1-28.

[30]. Oliner, S. D., \& Sichel, D. E. (2000). The Resurgence of Growth in the Late 1990s: Is Information Technology the Story? Washington, D.C.: Federal Reserve Board.

[31]. Ramdhani, M. A., \& Muhammadiyah, H. (2015). The Criteria of Learning Media Selection for Character Education in Higher Education. International Conference of Islamic Education in Southeast Asia. Malang: UIN Maulana Malik Ibrahim Malang.

[32]. Sari, S., Aryana, D. M., Subarkah, C. Z., \& Ramdhani, M. A. (2018) Multimedia Based on Scientific Approach for Periodic System of Element. IOP Conference Series: Materials Science and Engineering, $288(1), 012137$.

[33]. Farida, I., Helsy, I., Fitriani, I., \& Ramdhani, M. A. (2018). Learning Material of Chemistry in High School Using Multiple Representations. IOP Conference Series: Materials Science and Engineering, 228(2017), 012078.

[34]. Aisyah, R., Zakiyah, I. A., Farida, I., \& Ramdhani, M. A. (2017). Learning Crude Oil by Using Scientific Literacy Comics. Journal of Physics: Conference Series, 895(1), 012011

[35]. Sari, S., Anjani, R., Farida, I., \& Ramdhani, M. A. (2017). Using Android-Based Educational Game for Learning Colloid Material. Journal of Physics: Conference Series, 895(1), 012012.

[36]. Irwansyah, F. S., Lubab, I., Ramdhani, M. A., \& Farida, I. (2017). Designing Interactive Electronic Module in Chemistry Lessons. Journal of Physics: Conference Series, 895(1), 012009

[37]. Helsy, I., Maryamah, Farida, I., \& Ramdhani, M. A. (2017). VoltaBased Cells Materials Chemical Multiple Representation to Improve Ability of Student Representation. Journal of Physics: Conference Series, 895(1), 012010.

[38]. Irwansyah, F. S., Yusuf, Y. M., Farida, I., \& Ramdhani, M. A. (2018) Augmented Reality (AR) Technology on The Android Operating System in Chemistry Learning. IOP Conference Series: Materials Science and Engineering, 288(2017), 012068.

[39]. Ramdhani, M. A., \& Wulan, E. R. (2012). The Analysis of Determinant Factors in Software Design for Computer Assisted Instruction. International Journal of Scientific \& Technology Research, 1(8), 69-73. 